\title{
SUBSURFACE TEMPERATURES, GEOTHERMAL GRADIENTS AND HYDROCARBON STUDIES IN THE CALABAR FLANK
}

\author{
C. F. R. ODUMODU
}

(Received 15 May 2008; Revision Accepted 24 July 2008)

\begin{abstract}
Data gathered from seven exploratory wells were used to estimate geothermal gradients in the Calabar flank. Geothermal gradients vary between $34^{\circ} \mathrm{C} / \mathrm{km}$ to $51^{\circ} / \mathrm{km}$ with an average value of $43.5^{\circ} \mathrm{C} / \mathrm{km}$. The deeper formations such as the Awi Formation, the Nkalagu Formation and the Nkporo Shale records very high geothermald gradient values. These high geothermal gradients could result from nearness to the basement, volcanic emplacement or due to overpressuring usually associated with shales. The Benin Formation recorded lower geothermal gradient values which may have been caused by the free movement of groundwater in these continental sandstones. Geothermal gradient in the Calabar flank is higher on the Ituk high, while lower values were observed on the Ikang trough and the Ikpe platform. Hydrocarbon maturation studies suggest the Ameke Formation $\left(R_{0} \%<0.3\right)$ and the Imo Shale $\left(R_{0} \%=0.39-0.58\right)$ as being thermally immature and also reveal the Nkporo Shale $\left(R_{0} \%=0.70-1.02\right)$ and the Nkalagu Formation $\left(R_{0} \%=0.82-1.42\right.$ ) as having the potential to generate liquid hydrocarbon, while the Mfamosing Limestone $\left(R_{0} \%=1.43-2.13\right.$ ) is inferred as a likely gaseous hydrocarbon precussor. The presence of volcanic fragments in some of the sediments suggests possible thermal alteration of pooled hydrocarbons
\end{abstract}

KEYWORDS: Geothermal gradients. Hydrocarbon maturation, Bottom hole temperatures. Time temperature index

\section{INTRODUCTION}

Temperature and tıme plays a very important role in the maturation of organic matter into hydrocarbons. Bottom hole temperatures gotten from geophysical logs of petroleum exploratory wells are commonly used for geothermal and heat flow studies. However, several corrections are necessary before they can be utilized for geothermal and maturation studies.

This study deals with the temperature and geothermal history of the Calabar flank with a view to assess its potential for significant hydrocarbon accumulations. The geothermal gradients were evaluated using the least square techniques. Lopatin Waples modeling method, a technique which integrates time and temperature information in estimating maturation were utilized. The calculated Time temperature index (TTI) values were then correlated with other maturation Indices such as vitrinite reflectance $\left(R_{0} \%\right)$

\section{STRUCTURAL AND GEOLOGIC SETTING}

The Calabar flank is a sedimentary basin bordering South-eastern Nigeria's continental margin. It is at right angle to the major rift faults of the Benue Trough. It is also a down faulted margin that borders the Niger Delta on the South-eastern side and adjoins the NW-SE trending Oban massif. The Oban massif bound it to the north, Abakalikı trough to the north-west while the Cameroun volcanic line bounds the extension to the South-east. (Figure 1)

The stratigraphic succession in the Calabar flank has been described by several workers such as Reyment (1965). Murat (1972), Kogbe (1975), Adeleye and Fayose (1978), Odumodu (1994) and many others. A geological map of the Calabar flank is shown in Figure 2.

The stratigraphic fill in the Calabar flank (Table 1) starts from the basal fluvial grits and calcareous arkosic sandstones of the Awi Formation, which rests unconformably on weathered Precambrian Crystalline Basement Complex rocks (Adeleye and Fayose, 1978). The Awi Formation is probably of Aptian age. The Albian Mfamosing Limestone overlies the Awi Formation Overlying the Mfamosing Limestone is the Cenomanian - Turonian Nkalagu Formation. which is made up of a sequence of alternating dark grey shales with intercalations of thin calcareous limestone bands. This formation includes the Eze-Aku Shale. the Awgu Shale and the alternating shales and limestones of the Odukpani Formation. Some fragments of volcanic bodies have been found in the Nkalagu Formation at Anua- 1 and Ikono- 1 wells. The Nkalagu Formation is unconformably overlain by the Campanian Maastrichtian Nkporo Shale Tertiary to Recent sediments including the Imo Shale. the Ameke Formation and the Benın Sandstone overlıes the Nkporo Shale 


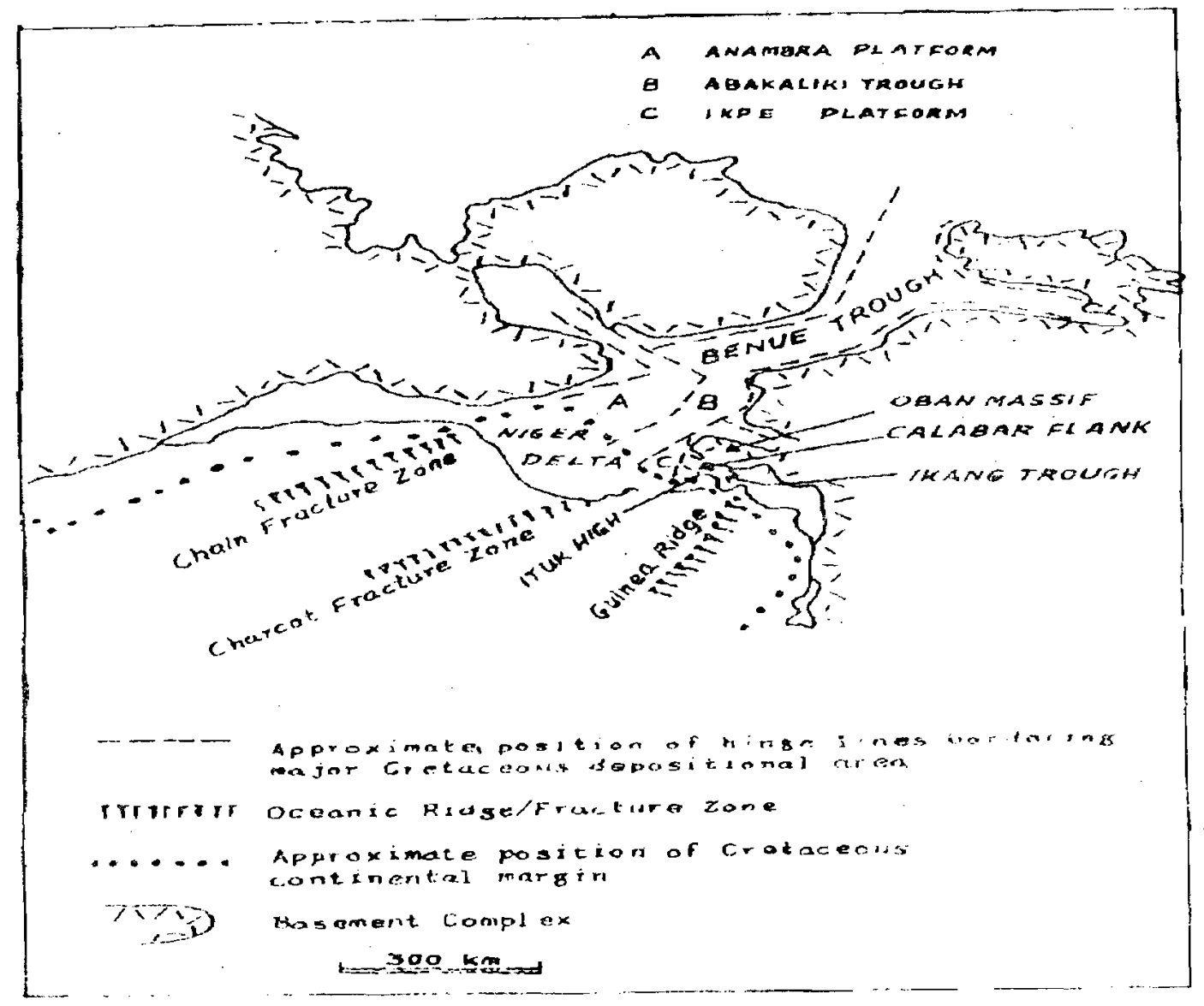

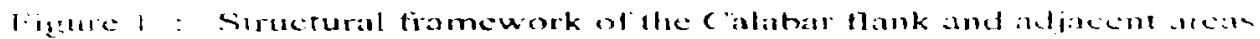

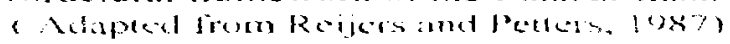

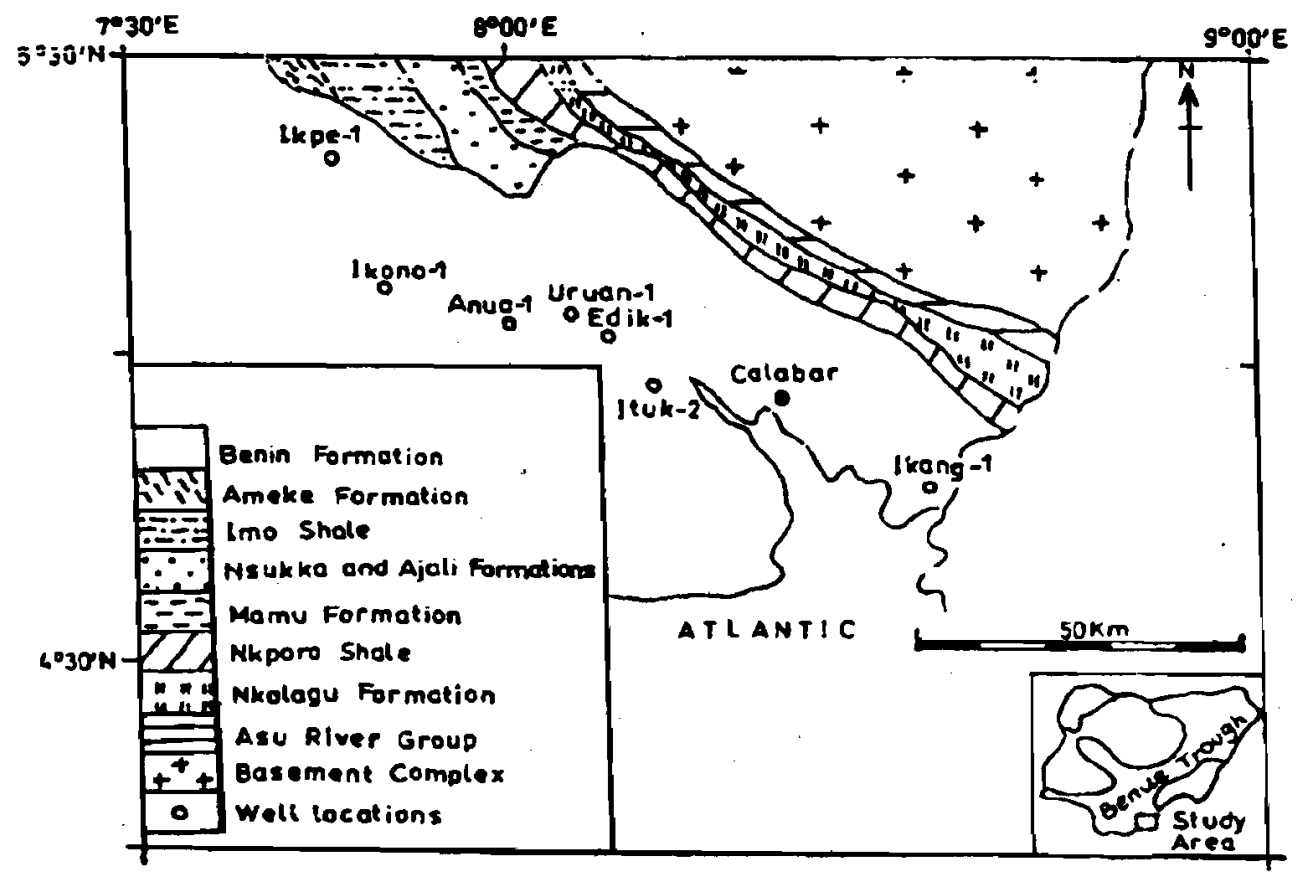

Figure 2 : Geologic sketch map of the Calabar flank with well locations 
Table 1: Stratigraphic sequence in the Calabar flank. Compiled from Reyment, 1965; Dessauvagie, 1968; Fayose, 1978; Ramanathan and Kumaran, 1981: Petters Alld Ekweozor, 1982.

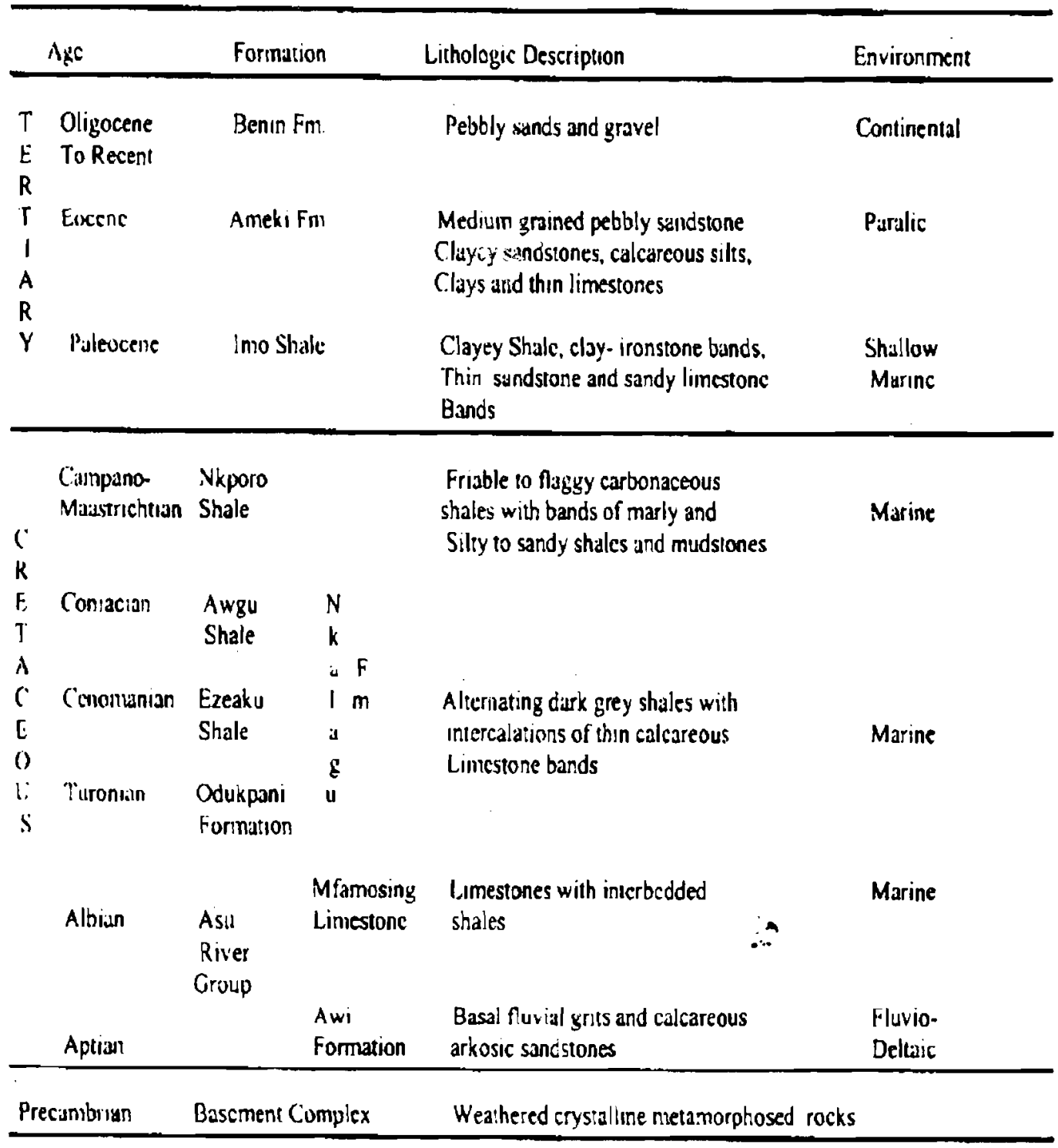

\section{METHOD OF STUDY}

\section{TEMPERATURE AND GEOTHERMAL GRADIENT VARIATIONS}

Geothermal gradient can be defined as an increase in temperature resulting from a corresponding increase in depth. Bottom hole temperatures (BHT) gotten from geophysical logs of petroleum exploratory wells are commonly used for geothermal and heat flow studies. However several corrections are necessary before a reasonable interpretation of temperature data can be made. Bottom hole temperatures are usually lower than static formation temperatures because of drilling disturbances such as the circulation of drilling mud

A method commonly used for correcting bottom hole temperatures (BHT) is the Horner technique (Chapman et al, 1984). It involves plotting the bottom hole temperatures according to the equation.

$$
T_{B}(t)=T_{B a}+A \log \left(t_{c}+t_{e} / t_{e}\right)
$$

Where $T_{B}(1)=$ the time dependent BHT

$\mathrm{T}_{\mathrm{B} O}=$ the true formation temperature

$t_{c}=$ the circulation time

$t_{e}=$ the elapsed time since circulation

$A=a$ constant

By plotting log $\left(t+t_{e} / t_{t}\right)$ against $T_{B}(t)$, one can estimate $T_{B}$ a as the ordinate intercept on the 
abscissa axis. This method was utilized by Chapman et al (1984) for the temperature data from Uinta Basin. Nwachukwu (1976) applied a modified Lachenbruch Brewer equation to correct bottom hole temperatures (BHT) for drilling effects. However this method requires multiple determinations of bottom hole temperatures at the same depth so as to use this correction procedure to obtain equilibrium temperature. The magnitude of differences between observed bottom hole temperatures $\mathrm{BHT}$ and corrected temperatures as discussed in some studies ranges from $5^{\circ} \mathrm{C}$ ( Handique and Bharali, 1981) to $10^{\circ} \mathrm{C}$ and $20^{\circ} \mathrm{C}$ ( Chapman et al, 1984). Handique and Bharali (1981) suggested that well $\log B H T$ are about $5^{\circ} \mathrm{C}$ lower than static formation temperature.

Leblanc et al (1981) suggested a method of correcting bottom hole temperatures based on Middleton (1979) curve matching techniques whereby thermal stabilization curves derived from an assumed thermal diffusivity are superimposed on actual data to estimate a true formation temperature. Leblanc's correction is done using the following relation.

$\operatorname{BHT}(0, t)=T m+\Delta T\left(e^{-82} / 4 k t\right) \ldots \ldots \ldots \ldots .2$

Where $\Delta_{T}=T_{f}-T_{m}$

$\mathrm{Tm}=$ the temperature of the drilling mud

$T_{f}=$ the formation temperature

$a=$ the drill hole radius

$k=$ the formation rock matrix diffusivity

$t=$ the total time of mud circulation at the depth of measurement.

However, neither the Horner's plot or Leblanc's method could be applied to this study because of lack of basic data as stated above that are required for these corrections.. The geothermal gradients at the various well sites as well as the average geothermal gradient were obtained by use of least square fit to the bottom hole temperatures (BHT) data.

\section{HYDROCARBON MATURATION}

The maturation of buried organic matter into hydrocarbons is largely a function of the temperature history of the sediment (Lopatin, 1971; Hunt, 1979 and Waples, 1980). The present day temperatures were used to estimate the paleotemperature. The estimated paleotemperatures were then superimposed on already established burial history curves. ( Figure 3 ). The degrees of maturation of organic matter in sediments were then calculated using Lopatin - Waples time temperature index (TTI) of maturity as given in equation.

$$
\begin{aligned}
& T T I=\sum_{n M i n}^{n M a x} \quad\left(\Delta T_{i}\right)\left(r_{i}^{n}\right) \ldots \ldots \ldots \ldots \ldots . . . .3 \\
& \text { Where } \Delta \mathrm{T} i=\text { Residence times and } \\
& r_{i}^{n}=\text { temperature coefficient of the }
\end{aligned}
$$$$
\text { rate of maturation and }{ }_{n} \text { max and }{ }_{n} \text { min }
$$
are respectively the index values of the highest and lowest temperature intervals encountered.

Organic maturation were evaluated for the Calabar flank, using the Lopatin - Waples modeling approach

\section{RESULTS AND DISCUSSION}

Temperature versus depth plot for the various wells as well as a generalized temperature depth plot for the Calabar flank are shown in Figures 4 and 5. A large variation in temperature and geothermal gradient values were observed in the Calabar flank. (Table 2, Figure 6). These variations are influenced by well position with respect to nearness to a source of heat such as basement, depth of burial of the sediment / formation and the hydraulic flow system. A summary of the geothermal gradient distribution in the Calabar flank is given in Table 2 and Figure 6 . The Awi Formation has a temperature gradient that ranges from 34.1 to $62.5^{\circ} \mathrm{C}$ l $\mathrm{km}$ (Table 2). The high temperature gradient observed in the formation is to a large extent been influenced by high temperatures diffusing from the basement. The lower temperature value observed in the Benin Formation resulted from convection currents set up by the free movement of groundwater in the continental sandstones of the Benin Formation. The Nkalagu Formation is another formation that recorded a high thermal gradient value that ranges from 48.7 to $66.9^{\circ} \mathrm{C} /$ $\mathrm{km}$. The high thermal gradient observed in the formation might have been influenced by some volcanic bodies lying within the sediments at Anua-1 and Ikono-1 wells. The Nkporo Shale has a variable thermal gradient ranging from 33.3 to $94.7^{\circ} \mathrm{C} / \mathrm{km}$. The high thermal gradient recorded in the Nkporo Shale could result from over pressuring often associated with shales. It can as well be induced by volcanics lying directly beneath the shales. 
(a)



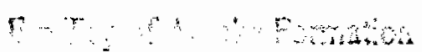

$D=$ Top of Imo Shale

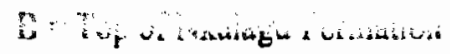

C = Top of Nkporo Shale

$A=$ Top of Mfamosing Limestone

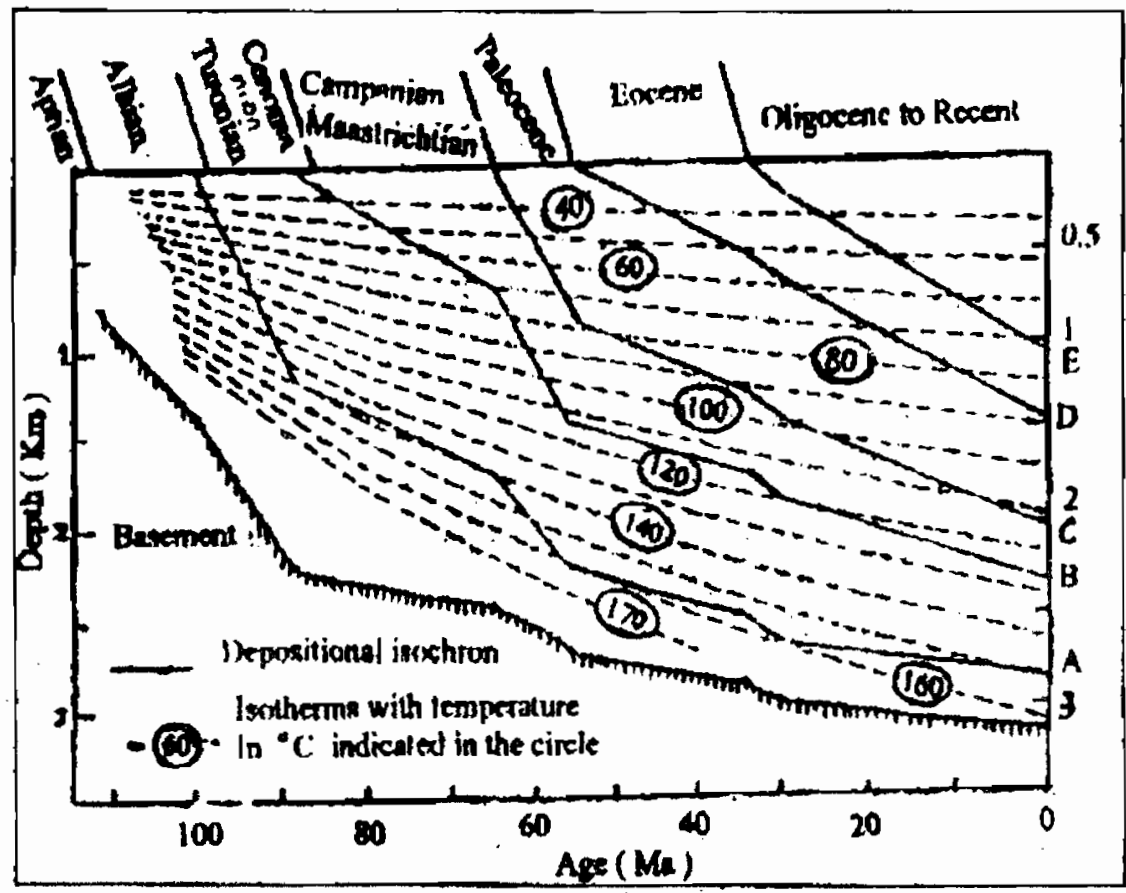

Figure 3 : Time / Temperature / Depth plot for (a) Ikpe - 1 and (b) Uruan - 1 wells : 
(c)

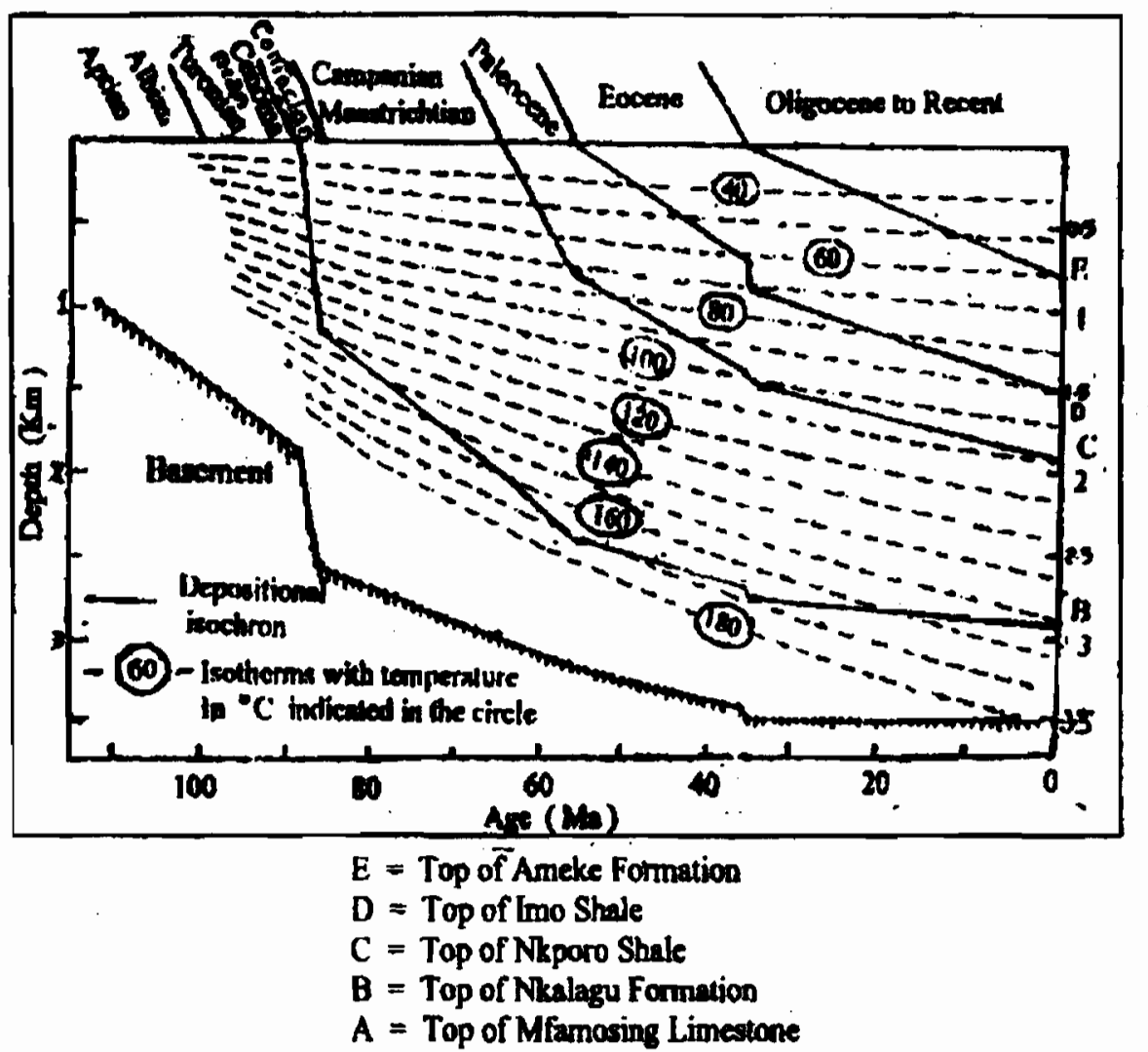

(d)

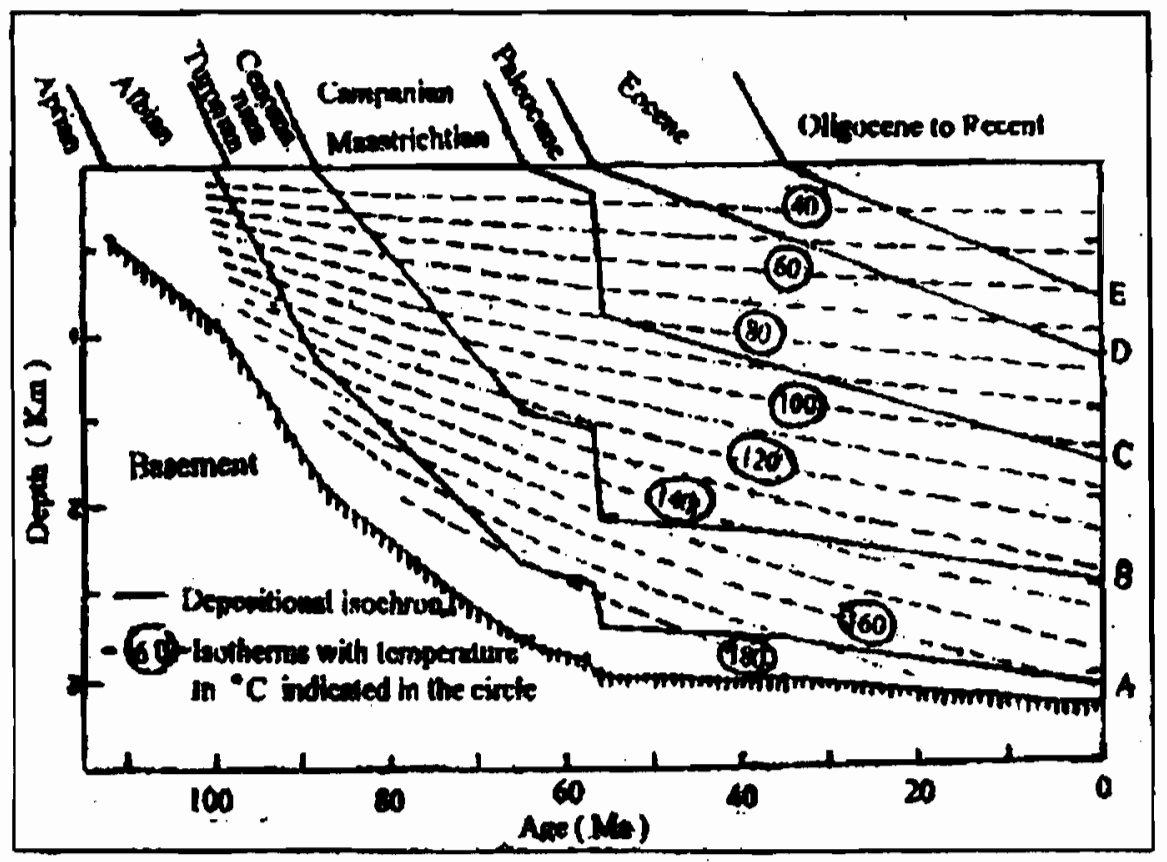

Figure 3: Time / Temperature / Depth plot for (a) Anus - 1 and (b) Ituk - 2 wells 


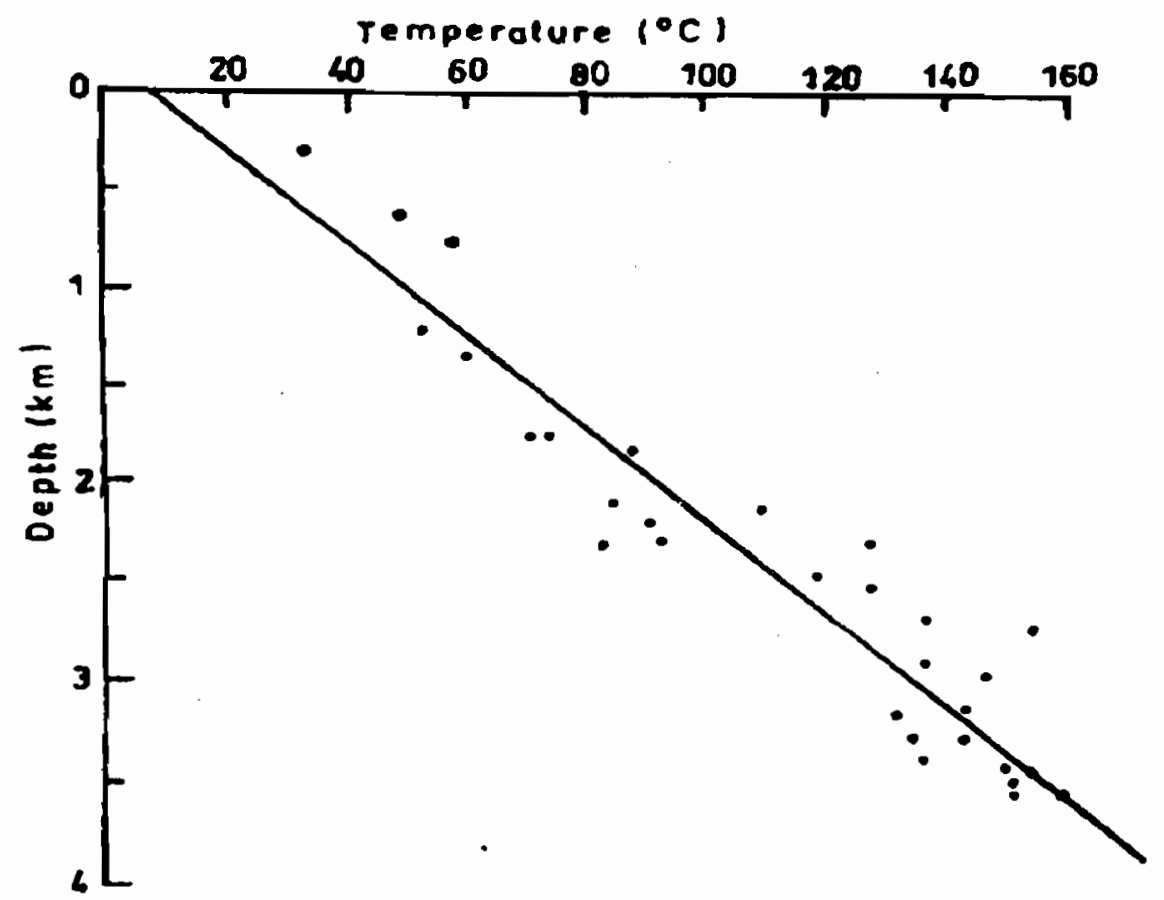

Figure 4 : Bottom Hole Temperatures ( BHT) versus Depth plot for all wells

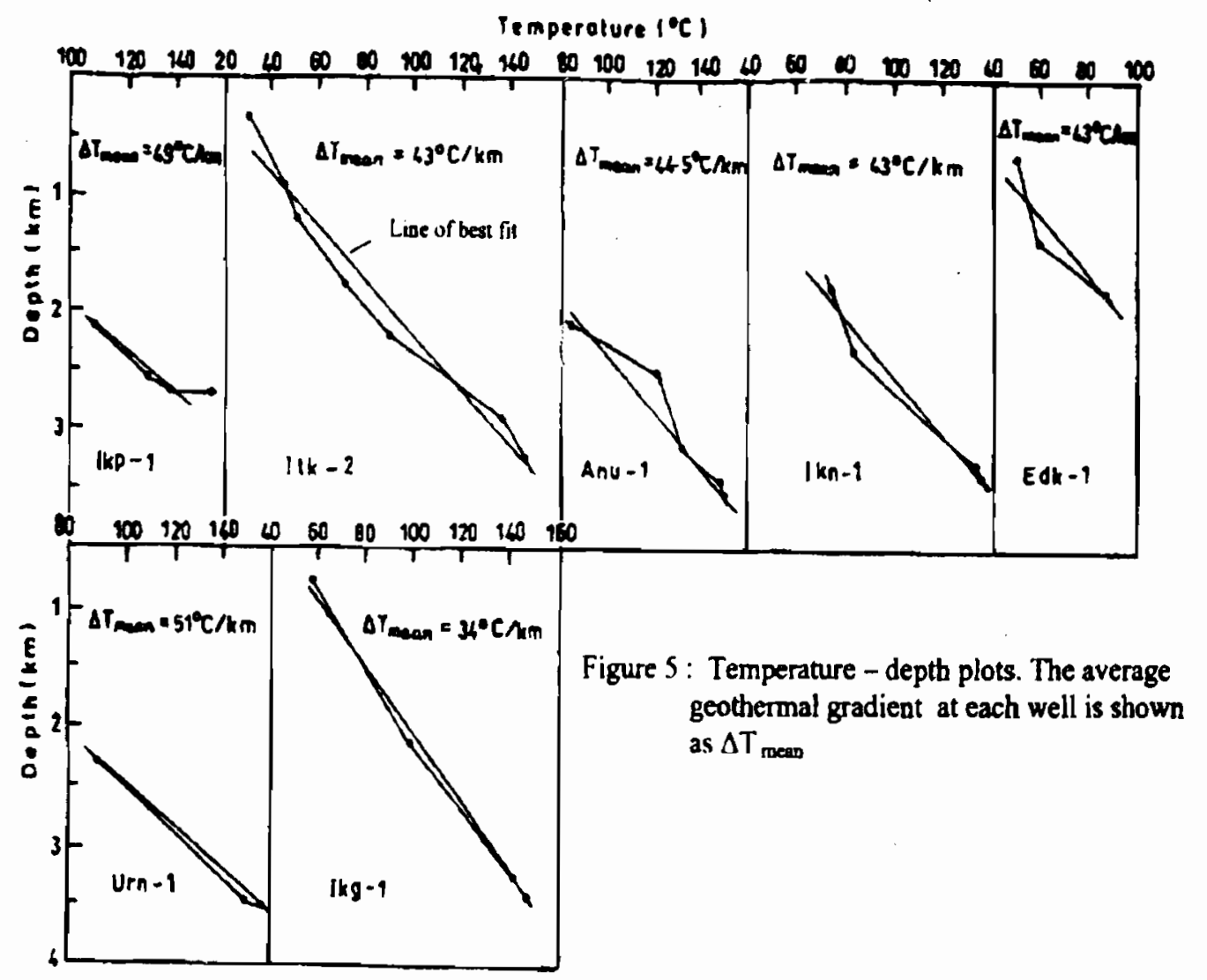


The geothermal gradjent in the Calabar fiank increases in a north-eastenty direction from the Niger detta to the Oban massif (Figure 7), which is in consonance with the earlier projections of Niger Delta based studies of Nwachukwu (1976) and Avbovbo (1978). The geothermal gradient is higher on the ltuk high but decreases towards the Ikpe platform and Ikang trough (Figure 7).

Possible source rocks for hydrocarbon maturation in the Calabar flank include the shales and limestones of the Mfamosing Limestone, the Nkalagu Formation, the Nkporo Shale, the Ameke Formation and the Imo Shale. The result of hydrocarbon maturation which was empirically calculated is given in table 3 . The calculated $T T I$ values were converted to vitrinite reflectance $\left(R_{0} \%\right)$ values using table 4 . The result of organic maturation of the source rocks (Table 3 ). suggests that the Ameke Formation $\left(R_{0} \%<0.3\right)$ and the Imo Shale $\left(R_{0} \%=0.39-0.58\right)$ in the Calabar flank as immature source rocks while the Nkporo Shale $\left(R_{0} \%=\right.$ $0.70-1.02)$ and Nkalagu Formation $\left(R_{0} \%=0.82-1.42\right)$ are mature enough to generate hydrocarbons. The Mfamosing Limestone $\left(R_{0} \%=1.43-2.13\right)$ is also considered to be within the light oil and condensate. Wet gas) preservation deadline.

Table 2: Summary of Geothemal Gradient variations in the Calabar flank

\begin{tabular}{|c|c|c|c|c|c|c|c|}
\hline $\begin{array}{l}\text { Wells } \\
\text { Formations }\end{array}$ & Ikpe-1 & Ikono-1 & Anua-1 & Uruan-1 & Edik-1 & Ituk-2 & Ikang-1 \\
\hline Benin Formation & & & & & & 21.8 & \\
\hline Ameke Formation & & & & & & 22.9 & 29.6 \\
\hline Imo Shale & & & & & 15.0 & 35.2 & 38.4 \\
\hline Nkporo Shale & & & 94.7 & \multirow{5}{*}{48.7} & & 46.0 & 33.3 \\
\hline Volcanics & & 54.7 & 65.6 & & & & 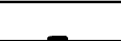 \\
\hline Nkalagu Formation & & & & & - & 66.9 & - \\
\hline Mfamosing Limestone & $\overline{45}$ & 17.7 & 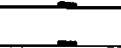 & & - & 25.6 & 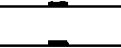 \\
\hline Awi Formation & 625 & - & - & & - & 34.1 & - \\
\hline Basement & & & & 131.1 & & & \\
\hline
\end{tabular}

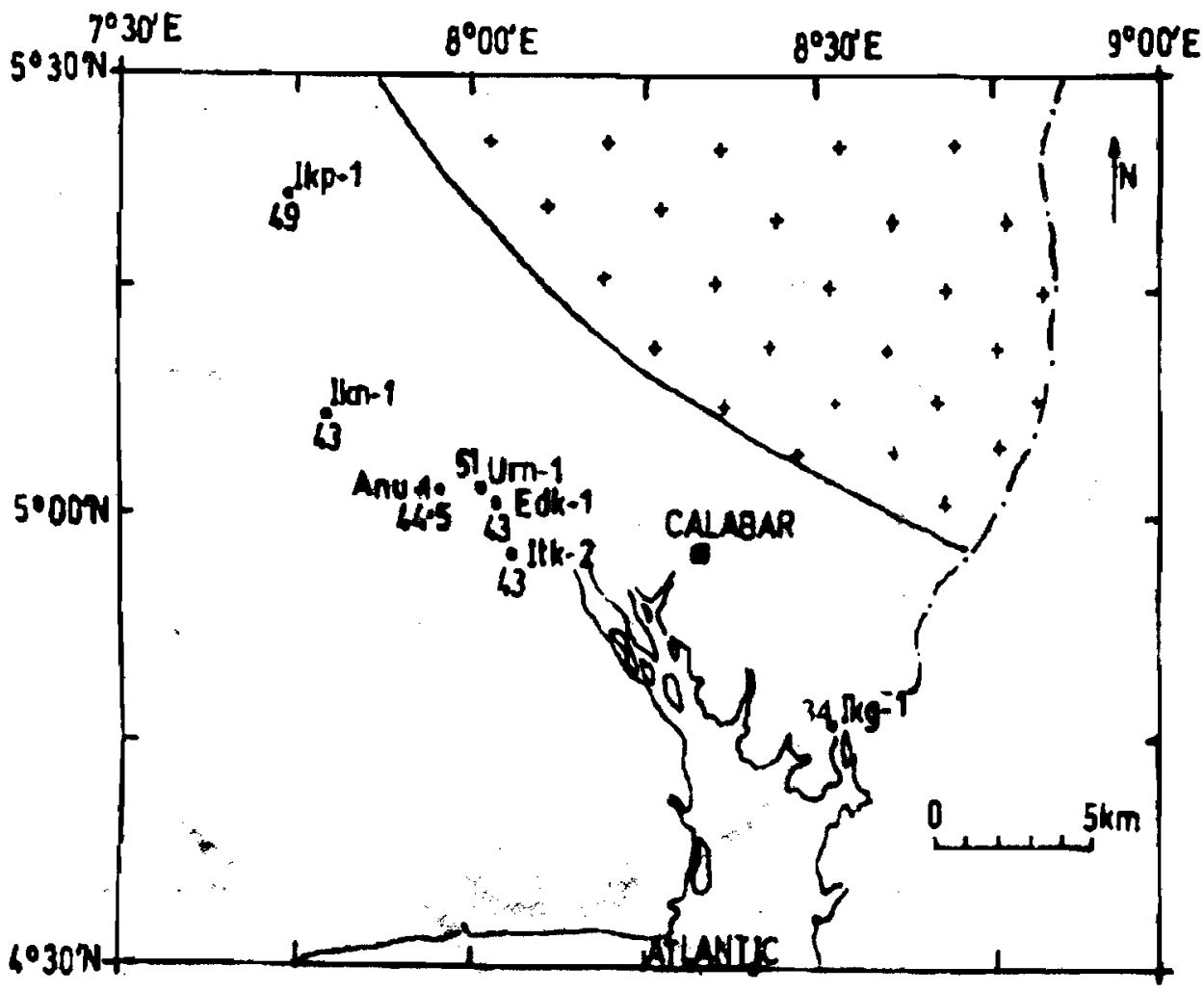

Figure 6 : Grad T variations across the Calabar flank ( vajues are in ${ }^{\circ} \mathrm{C} / \mathrm{Km}$ ). 


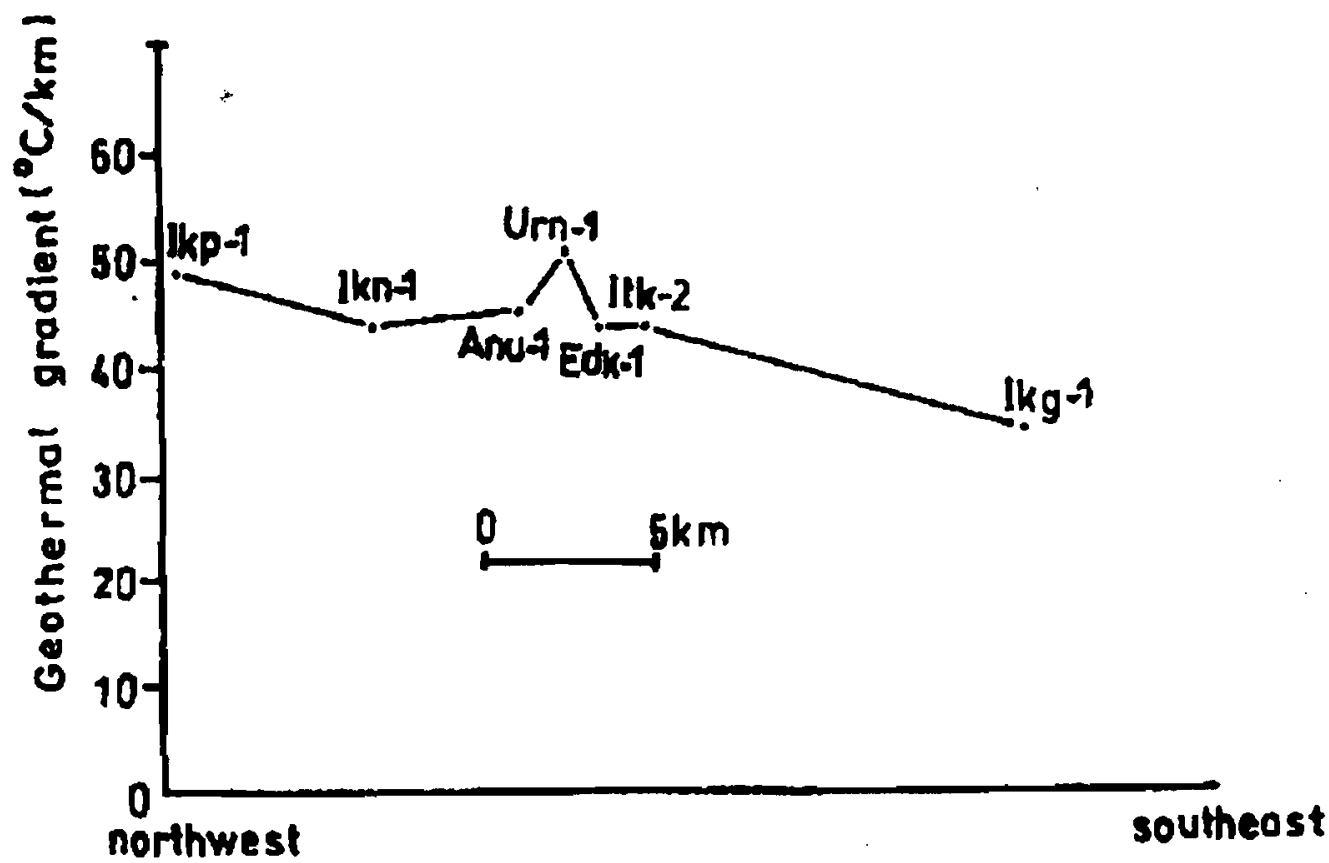

Figure 7 : Geothermal gradient variations along northwest - southeast direction

\section{CONCLUDING REMARKS}

Geothermal gradients in the Calabar flank varies from $34^{\circ} \mathrm{C} / \mathrm{Km}$ to $51^{\circ} \mathrm{C} / \mathrm{Km}$ with an average value of $43.5^{\circ} \mathrm{C} / \mathrm{Km}$. Geothermal gradients are generally higher for the deeply buried formations such as the Awi Formation, the Nkalagu Formation and the Nkporo Shale. Such factors such as closeness to basement, volcanic emplacement, overpressuring often associated with shales may have influenced this high thermal stress. Lower thermal gradient values occur within the Benin Formation and this can be attributed to the free movement of groundwater in the continental sandstone. Geothermal gradients in the Calabar flank generally increases in a northeasterly direction from the Niger Delta to the Oban Massif The geothermal gradients in the Calabar flank is generally higher on the Ituk high than at the ikpe platform than the Ikang trough.

Hydrocarbon maturation modeling which has been evaluated for the Calabar flank by superimposing paleotemperatures on already established burial history curves suggests that some of the source rocks have undergone proper temperature conditions and requisite exposal time for the maturity status to be attaned This study has shown that the Ameke Formation $\left(R_{0} \%<0.3\right)$ and the Imo Shale $: R \%=039-058$ ) are thermally immature. The Nkporo Shale $\left(R_{0} \%=0.70-1.02\right)$ and Nkalagu Formation $\left(R_{0} \%=0.82-1.42\right)$ has been revealed as having the potential to generate liquid hydrocarbon, while the Mfamosing Limestone $\left(R_{0} \%=\right.$ $1.43-2.13$ ) has the capacity for light oil and wet gas generation. However, all the wells drilled in the Calabar flank were dry wells except at Ikono - 1 well where little gas was encountered. The non discovery of oil in the Calabar flank is still a mystery. Absence of suitable traps and possible migration of generated hydrocarbons out of the flank to the adjoining Niger Delta could be possible explanations of this problem. Other possible ideas about this issue might be the conversion of generated oil to gas due to high temperatures associated with volcanic bodies that were emplaced within the sediments.

One limitation encountered in this study was the lack of some basic data required for the correction of bottom hole temperatures (BHT) to static formation temperature. This lack therefore necessitated using the raw data without corrections. This may result to an underestimation in the maturation status of the source rocks because bottom hole temperatures are usually lower than static formation temperatures. It is therefore recommended that more data should be made available for future studies. 
Table 3: Calculated TTI values with their Equivalent Vitrinite reflectance $\left(R_{0} \%\right)$ values for the $I_{k p e}-1$, Anua-1, Ituk-2, and Uruan -1 wolls, all in the Calabar flank.

\begin{tabular}{|c|c|c|c|c|c|c|c|c|c|}
\hline Wells & Ikpe-1 m & & Anua-1 & & Ituk-2 wet & & Uruan-1 $n$ & & \\
\hline $\begin{array}{l}\text { Maturation } \\
\text { Indices } \\
\text { Formation }\end{array}$ & $\begin{array}{l}\pi 1 \\
\text { Values }\end{array}$ & $\begin{array}{l}\mathbf{R}_{\mathbf{0}} \% \\
\text { Values }\end{array}$ & $\begin{array}{l}T 1 \\
\text { Values }\end{array}$ & $\begin{array}{l}\mathbf{R}_{0} \% \\
\text { Values }\end{array}$ & $\begin{array}{l}\text { TTI } \\
\text { Values }\end{array}$ & $\begin{array}{l}R_{0} \% \\
\text { Values }\end{array}$ & $\begin{array}{l}\pi \mathrm{TI} \\
\text { Values }\end{array}$ & $\begin{array}{l}\mathbf{R}_{\mathbf{0}} \% \\
\text { Values }\end{array}$ & $\begin{array}{l}\text { Remarks/l } \\
\text { nterpretati } \\
\text { on. }\end{array}$ \\
\hline $\begin{array}{l}\text { Ameke } \\
\text { Formation }\end{array}$ & - & - & 0.625 & $<0.3$ & 0.968 & $<0.3$ & 0.172 & $<0.3$ & Immature \\
\hline Imo Shale & - & - & 8.766 & 0.58 & 5.235 & 0.53 & 1.169 & 0.39 & Immature \\
\hline $\begin{array}{l}\text { Nkporo } \\
\text { Shale }\end{array}$ & 0.357 & $<0.3$ & 80.028 & 1.02 & 26.956 & 0.76 & 20.194 & 0.70 & Mature \\
\hline $\begin{array}{l}\text { Nkalagu } \\
\text { Formation }\end{array}$ & 36.435 & 0.82 & 352.124 & 3.54 & 99.668 & 1.10 & 231.689 & 1.42 & Mature \\
\hline $\begin{array}{l}\text { Mfamosing } \\
\text { Limestone }\end{array}$ & 238.071 & 1.43 & - & _ & $1,064.00$ & 2.06 & 1277.631 & 2.13 & $\begin{array}{l}\text { Light Oil } \\
\text { and wet } \\
\text { gas }\end{array}$ \\
\hline
\end{tabular}

Table 4: Correlation of TTI with threshold values of hydrocarbon generation and preservation.

(After Waples, 1980)

\begin{tabular}{|l|l|l|l|}
\hline Stage & $\mathrm{TTI}$ & $\mathrm{R}^{0}$ & $\mathrm{TAI}$ \\
\hline Onset of oil generation & 15 & 0.95 & 2.65 \\
\hline Peak of oil generation & 75 & 1.00 & 2.90 \\
\hline End of oil generation & 160 & 1.30 & 3.20 \\
\hline Light oil (API<40 $)$ Preservation deadline & 500 & 1.75 & 3.60 \\
\hline Oil (API<50) Preservation deadline & 1000 & 2.00 & 3.70 \\
\hline Condensate (Wet Gas ) preservation deadline & 15000 & 2.20 & 3.70 \\
\hline Dry Gas Methane & $>65.000$ & 4.50 & $>4.00$ \\
\hline
\end{tabular}

\section{ACKNOWLEDGEMENTS}

The author is grateful to SPDC and NNPC for providing the data sets used for this research.

\section{REFERENCES}

Adeleye, D R. and Fayose, E. A., 1978. Stratigraphy of the type section of the Awi Formation. , Odukpani area, Southeastern Nigeria. Joumal of Mining and Geology, 15: $33-37$

Aubovbo, A A., 1978. Geothermal gradients in southeastern Nigerian basin. Bulletin Canadian Association of Petroleum Geologists, 26: 269 274.

Chapman, D. S., Keho, T. H. and Picard, M. D., 1984. Heat flow in Uinta basin determined from bottom hole temperature (BHT) data. Geophysics, 49: $453-466$.
Dessauvagie, T. F. J., 1968. Cenomanian Trocholinas from Nigeria. Micropaleontology, 14: 64-72.

Fayose, E. A., 1978. Depositional Environments of carbonates, Calabar flank, Nigeria. Journal of Mining and Geology, 15: 1- 13 .

Handique, G. K. and Bharali, B., 1981. Temperature Distribution and its relation to hydrocarbon accumulation in Upper Assam valley, India. American Association of Petroleum Geology bulletin, 65 (9): 151-171.

Hunt, J. M., 1979. Petroleum geochemistry and geology: San Francisco and Freeman \& Co., 617 pp.

Kogbe, C. A., 1975. Paleogeographic history of Nigeria from Albian times. In Kogbe C.A. (ed.) Geology of Nigeria, Lagos. Elizabethan Publishing Company. pp $237-252$

Leblanc, Y., Pascoe, L. J. and Jones, F. W., 1981. The temperature stabilization of a borehole. Geophysics, 45: $1301-1303$. 
Lopatin, N. V., 1971. Temperature and geologic time as factors of coalification (in Russian), Akad. Nauk. SSSR. IZV. Serv. Geol., No 3: 95 - 106.

Middleton, M. F., 1979. A model for bottom hole temperature stabilization of a borehole. Geophysics, 46: 1301 - 1303.

Murat, R. C., 1972. Stratigraphy and Paleogeography of the Cretaceous and Lower Tertiary in Southem Nigeria. In Desauvagie, T.F.J. and Whiteman, A.J. (ed.) African Geology, Ibadan, Nigeria, University of Ibadan, pp $251-266$.

Nwachukwu, J.I., 1976. Approximate geothermal gradient in Niger delta sedimentary basin. American Association of Petroleum Geologist bulletin., 60: $1073-1077$.

Odumodu, C. F. R., 1994. Subsidence and Hdrocarbon maturation in the sediments of the Calabar flank, southeastem Nigeria. Unpublished M.Sc. thesis. Department of Geology. University of Calabar, Nigeria. 138 pp.

Petters, S. W. and Ekweozor, C. M., 1982. Petroleum geology of Benue Trough and Southeastem
Chad basin, Nigeria. American Association of Petroleum Geologist bulletin., 66 (8): 1141 1149.

Ramanathan, R. M. and Kumaran, K. P. N., 1981. Age and Paleoecology of $\mathrm{M-1}$ well in the Calabar flank, Southeastern Nigeria. Joumal of Mining and Geology., 18, :163 - 171.

Reijers, T. J. A. and Petters, S. W., 1987. Depositional environments and Diagenesis of Albian carbonates on the Calabar flank, SE Nigeria. Joumal of Petroleum Geology., 10 (3): 283 294.

Reyment, R. A., 1965. Aspects of the geology of Nigeria. University of Ibadan, Nigeria, pp 145.

Waples, D. W., 1980. Time and Temperature in petroleum formation. Application of Lopatin's method to petroleum exploration. American Association of Petroleum Geology bulletin, 64 : 916 - 926

Whiteman, A. J., 1982. Nigeria: Its petroleum geology, resources and potential. Vols I and II. Graham and Trotham, London. $394 \mathrm{p}$. 